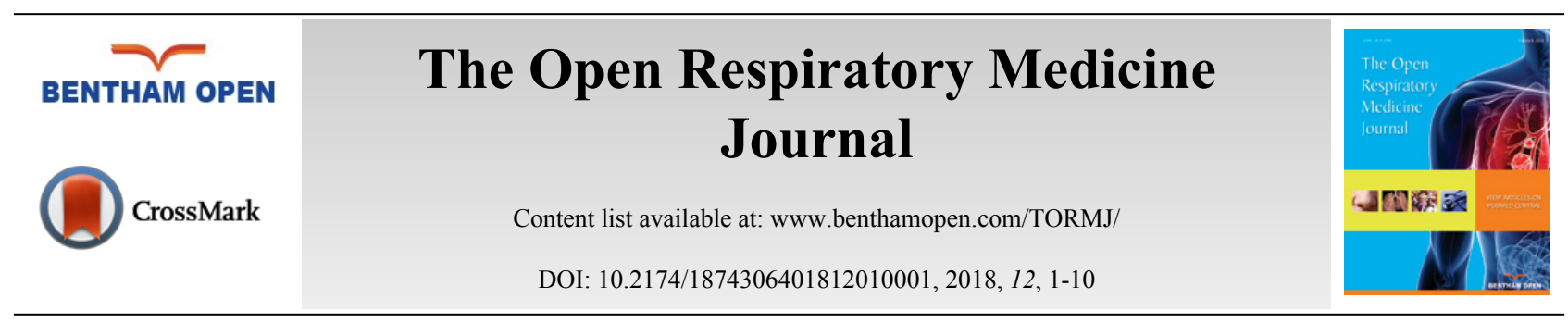

REVIEW ARTICLE

\title{
Gastric Aspiration and Its Role in Airway Inflammation
}

\author{
E.B. Hunt ${ }^{1,2}$, A. Sullivan ${ }^{3}$, J. Galvin ${ }^{3}$, J. MacSharry $^{3}$ and D.M. Murphy ${ }^{1,2, *}$ \\ ${ }^{I}$ The Department of Respiratory Medicine, Cork University Hospital, Cork, Ireland \\ ${ }^{2}$ The Health Research Board Clinical Research Facility, University College Cork, Cork, Ireland \\ ${ }^{3}$ The APC Microbiome Institute, Schools of Medicine and Microbiology, University College Cork, Ireland
}

Received: November 30, 2017

Revised: December 22, 2017

Accepted: January 1, 2018

\begin{abstract}
Gastro-Oesophageal Reflux (GOR) has been associated with chronic airway diseases while the passage of foreign matter into airways and lungs through aspiration has the potential to initiate a wide spectrum of pulmonary disorders. The clinical syndrome resulting from such aspiration will depend both on the quantity and nature of the aspirate as well as the individual host response. Aspiration of gastric fluids may cause damage to airway epithelium, not only because acidity is toxic to bronchial epithelial cells but also due to the effect of digestive enzymes such as pepsin and bile salts. Experimental models have shown that direct instillation of these factors to airways epithelia cause damage with a consequential inflammatory response. The pathophysiology of these responses is gradually being dissected, with better understanding of acute gastric aspiration injury, a major cause of acute lung injury, providing opportunities for therapeutic intervention and potentially, ultimately, improved understanding of the chronic airway response to aspiration. Ultimately, clarification of the inflammatory pathways which are related to micro-aspiration via pepsin and bile acid salts may eventually progress to pharmacological intervention and surgical studies to assess the clinical benefits of such therapies in driving symptom improvement or reducing disease progression.
\end{abstract}

Keywords: Reflux, Medicine, Inflammation, Lung Injury, Epithelium, Cytokines.

\section{BACKGROUND}

Gastro-Oesophageal Reflux Disease (GORD) affects approximately $20 \%$ of the population of the western world [1]. The possible relationship between GORD and airways disorders has long been postulated. While physicians generally acknowledge a link between oesophageal disorders and respiratory disease, this relationship is complex and may manifest in a variety of clinical ways. In particular, Gastro-Oesophageal Reflux (GOR) seems to be frequently present in patients with advanced lung diseases [2].

Gastro-oesophageal reflux is caused by stomach contents leaking into the oesophagus, which in turn has the potential to lead to aspiration of these contents into the adjoining respiratory tract. In healthy subjects, the amount of aspirated material is usually small and can be cleared by host defense mechanisms without consequence. However, if aspiration is to result in adverse clinical consequences, the nature of the evolving illness will be dependent on the nature and volume of the aspirated material, the temporal nature of the insult, and the elicited host responses [3]. Aspiration of large amounts of gastric acid will result in the induction of a chemical injury to the airways and lung parenchyma. The initial insult triggers a cascade of inflammatory responses with the recruitment of inflammatory cells and the release of various inflammatory mediators [4]. Large volume gastric acid aspiration may cause an acute lung injury, with diffuse alveolar damage and pneumonitis. In contrast, recurrent small volume aspiration during sleep appear may be without consequence or result in chronic and less severe forms of lung injury [3]. Damage to the airway epithelium from aspiration of gastric fluids may be due to the toxicity of its low $\mathrm{pH}$, (with Song et al. having previously demonstrated normal airway $\mathrm{pH}$ to be 7.3 independent of airway size) [5]. In vivo and in vitro models have examined the effect of

\footnotetext{
* Address correspondence to this author at the The Department of Respiratory Medicine, Cork University Hospital, Wilton, Cork, Ireland, Tel: +353 21 492200, Fax: +353 21 4920168; E-mail: Desmond.murphy@hse.ie
} 
acid aspiration on lung injury and inflammation, using hydrochloric acid, with a $\mathrm{pH}$ ranging from 1 to 1.5 . Davidson $e t$ al. crucially demonstrated that gastric particles (both acidified and non-acidified) were also found to contribute to lung injury [6]. It had previously been shown that neutrophil influx into the lungs is mediated via an interleukin-6 (IL-6) and IL-8 pathway with Sacco et al. demonstrating a relationship between acidity and aspiration, increased IL-8 levels and airway neutrophil counts in asthmatic patients [7].

In those individuals who aspirate, recurrent respiratory tract infections are a common consequence, with the ensuing development of bronchiectasis a possible end-stage manifestation. Normal inflammatory responses to infection exhibited by macrophages are blunted due to weakly acidic conditions [8]. In the Cystic Fibrosis (CF) pig model, loss of antimicrobial peptide activity causes a reduction in bacterial killing, as a direct consequence of a reduction in airway surface liquid $\mathrm{pH}$ [9]. Epithelial regulation of local immunity through secretion of chemoattractants such as IL-8 in response to infection has been postulated with Hackett et al. showing that a weakly acidic environment might blunt this response [10]. In a cohort of patients prone to micro-aspiration they investigated whether or not lipopolysaccharides (LPS)-induced expression of inflammatory/chemotactic proteins was modulated by an acidic environment [11]. In cells exposed for 4 hours at weakly acidic pH, LPS-induced cytokine expression was reduced. Expression was further reduced on 16 hours exposure to low $\mathrm{pH}$, but this time a significant decrease in cell viability was also noted. The authors subsequently observed a significant reduction in LPS-induced cytokine production following weakly acidic shock treatment and subsequent prolonged exposure to endotoxin at normal $\mathrm{pH}$, in turn potentially compromising the response to infection through the reduction in cytokine production and the potential for subsequent diminished immune cell recruitment.

Recent research has shown that microbiological growth from gastric juice occurred when gastric juice $\mathrm{pH}$ was $>4$ and that the gastric and airway microbiome compositions of people with CF who reflux are similar in profile. This novel data suggests the existence of an aero-digestive microbiome in $\mathrm{CF}$, which may ultimately have clinical relevance. This host response to aspiration as well as its potential to induce changes in the pulmonary microbiome needs further investigation, with its importance only gradually gaining widespread recognition [12 - 14].

\section{PEPSIN AND BILE ACIDS}

The acidity of gastric fluids might not be the only potential mechanism of airways damage and a pro-inflammatory response to aspiration. It is possible that digestive enzymes such as pepsin and Bile Acids (BA) may also play roles as mediators of this airway response to aspiration injury.

Pepsin is stored as inactive pepsinogen in the chief cells of the gastric mucosa. It is a protease involved in the digestion of food, and its activity is acid-dependent. The conversion of pepsinogen to pepsin in the stomach starts slowly at $\mathrm{pH} 6$ and reaches optimal activity between $\mathrm{pH} 1.5$ to 2.5. Above $\mathrm{pH} 6.8$, pepsin becomes inactive and above $\mathrm{pH} 7.5$ it is fully inactive and irreversibly denatured [15]. In human gastric fluid, the pH ranges from 1.5 to 3 , which allows optimal pepsin activity, and the concentration of pepsin varies from 0.5 to $1 \mathrm{mg} / \mathrm{ml}$ [16].

In recent years, there has been an increasing acceptance of measured pepsin within the airways as representing an important and reliable biomarker for gastric aspiration [17 - 19]. Detectable airway pepsin has been associated with broncho-pulmonary dysplasia in children and with post lung transplant allograft rejection [20, 21]. Clinical and scientific experimental studies are needed to delineate whether pepsin is solely a marker of aspiration, or whether these associations are in part due to the pathological actions of pepsin. Amplification of cell and tissue damage may be a result of the combined breakdown of protein by pepsin and independent acid damage. In oesophageal tissue of rabbits, increased tissue damage has been demonstrated with exposure to pepsin in acid as compared to the tissue damage caused by the action of acid administered in isolation [22]. The cytotoxicity and inflammation caused by a combination of acid and pepsin on airway epithelium has, to date not been fully defined.

Utilizing a bronchial epithelial cell model, Bathoorn et al. found pepsin to be both cytotoxic and to induce an inflammatory response in cells [23]. Pepsin-induced cytotoxicity to human bronchial epithelial (16HBE) cells is pHdependent, with the greatest effect seen at the lowest acidity. Similarly, pepsin-mediated IL-6 and IL-8 release is optimized through lowering the $\mathrm{pH}$ of the media. In vivo studies have found that erosive lesions in esophageal epithelium exposed to pepsin are caused by the destruction of junctional molecules, with similar lesions described in the airways following gastric fluid aspiration [22].

Gastro-oesophageal reflux-derived bile acids have been detected in the Bronchoalveolar Lavage (BAL) fluid and sputum of patients with GOR (and co-existent respiratory conditions) at concentrations ranging from $0.4 \mu \mathrm{M}$ up to 32 
$\mu \mathrm{M}[24,25]$. A predisposition to pulmonary infection has been associated with Bile Acid (BA) aspiration in several studies [25 - 29], including infection with Pseudomonas aeruginosa, an important pathogen associated with several respiratory diseases. This is particularly relevant in the $\mathrm{CF}$ patient population, as the presence of pseudomonas in the $\mathrm{CF}$ airway is associated with increased morbidity and mortality [30, 31]. Bile acid aspiration has been linked with airways inflammation, with a correlation between alveolar neutrophils and interleukin-8 (IL-8) with BAL fluid BAs described in post- lung transplant and cystic fibrosis populations [25, 26, 29].

Bile acid aspiration has also been associated with increased BAL tumor necrosis factor alpha (TNF- $\alpha$ ) in a rodent model of chronic aspiration, leading to downstream pro-inflammatory cascade. However, the definitive mechanisms underpinning the impact of BA aspiration on lung inflammation and infection remain poorly elucidated. It is possible that the presence of BAs in the airways may trigger host factors, such as transcription factors, which in turn may modulate the ensuing immune response pathways. One potential target is hypoxia-inducible factor 1 (HIF-1). HIF-1 has been characterized to be an emerging master regulator in the host response to infection [32 - 35] and inflammation [36]. HIF-1 induces genes involved in the host immune response, such as nitric oxide, antimicrobial peptides, and several cytokines, including TNF- $\alpha$, which have been demonstrated to play an important role in containing infection [37]. Legendre et al. proposed that the suppression of HIF-1 signaling by BAs may have a significant influence on the progression and outcome of respiratory disease. They further found that the effects of BAs on cytokine production could at least as important as bacterium-mediated responses [38].

The inflammatory cascade that results from direct caustic action of $\mathrm{pH}$ and the exposure to acidic gastric aspirate has been well established but what of the non-acidified gastric aspirate? There is growing evidence from animal studies for small $(\sim 10 \mathrm{~mm})$ non-acidified gastric particles (SNAPs). Studies using tracheal instillation of SNAPs in rats demonstrated an acute neutrophilic inflammatory response at 4-6 hours. The initial oedema seen in previous studies using the aspiration of dilute hydrochloric acid (HCL) to form an animal model, was however not seen [39]. Acute inflammatory markers including TNF- $\alpha$, CXCL2 and CINC-1 were found to be elevated in the BAL from rats [40, 41]. It has been postulated that the presence of Monocyte Chemoattractant protein-1 (MCP-1/CCL2) may be responsible for the innate pulmonary inflammatory response and the development of granuloma. CCL2 is produced by numerous cells including vascular endothelial cells and alveolar type II pneumocytes. Mounting evidence suggests that CCL2 and its haematopoietic cell receptor CC Chemokine Receptor 2 (CCR2) are involved in inflammatory disorders of the lung. In animal models of allergic asthma, idiopathic pulmonary fibrosis (IPF), and bronchiolitis obliterans syndrome (BOS), CCL2 expression and protein production are increased and the disease process is attenuated by CCL2 immunoneutralization. Postulated mechanisms of action include recruitment of regulatory and effector leukocytes; induction of fibroblast production of transforming growth factor- $\beta$ (TGF- $\beta$ ) and pro-collagen; stimulation of histamine or leukotriene release from mast cells or basophils; and enhancement of Th2 polarization [42].

In truth, the severity of injury associated with gastric aspiration is as a result of a combination of the two insults, both acid and SNAP. In both rat and murine models, the severity of lung injury from a combined injury is more severe than for either SNAP or as a result of acid exposure alone [40, 43, 44]. Levels of albumin in BAL, which when raised, is associated with the loss of membrane integrity, are significantly higher in those rats exposed to the dual insult. There is in fact an observed synergistic response that may account for the increased severity of lung injury observed, one that is far greater than injury levels occurring with individual component injuries alone. Neutrophils (numbers) are dramatically increased in rodent BAL who have been subjected to a dual insult compared to acid or SNAP alone. These levels remain high 48 hours post aspiration, indicating leukocytic infiltration [40]. Levels of CINC-1 (rat homologue of IL-8), IL-10, CCL2 were also elevated in those exposed to dual insult compared to ACID or SNAP alone. In this model, IL-10 levels were the single best predictor of lung injury severity [40]. This finding is consistent with the interpretation that increases in this anti-inflammatory (down-modulatory) cytokine are important in protective responses against acute inflammation. Treatment with IL-10 reduces the influx of inflammatory cells and suppressed the expression of IL-6, $\mathrm{TNF} \alpha$ and CXCL2. Upon exposure, NF- $\mathrm{KB}$ activation is one of the first pulmonary responses, and it occurs before the detection of any increase in pro-inflammatory cytokines [45]. Nuclear factor- $\kappa \mathrm{B}$ controls the expression of some 200 target genes, many of which are involved in inflammation, such as adhesion molecules, interleukins, chemokines, acute phase response genes and cytokines [46]. In Li. et al's study, treatment with exogenous IL-10 reduced NF- $\kappa \mathrm{B}$ p65 expression, which might mediate the suppressive action of IL-10 on the formation of these pro-inflammatory cytokines and subsequent inflammation [47]. 


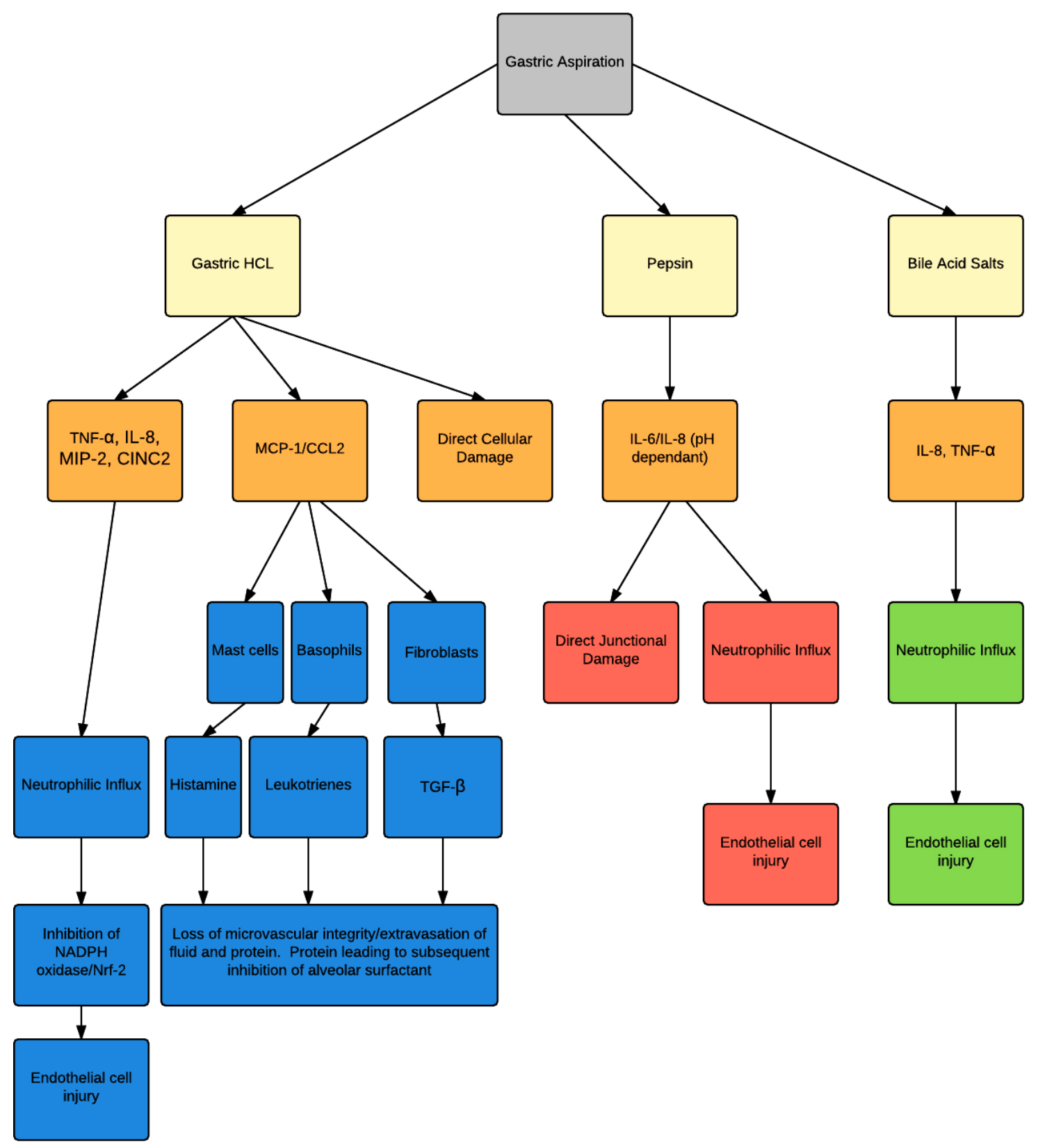

Fig. (1). Gastric aspiration and the complex inflammatory cascade in airway epithelium and endothelium. Direct and indirect pathways when exposed to acid environment as well as the parallel pathways involving pepsin and bile salts, ultimately leading to endothelial damage, and acute and chronic lung injury. TNF- $\alpha$ (Tumour necrosis factor- $\alpha$ ), IL-8 (Interleukin-8), MIP-2 (macrophage inflammatory protein), CINC2 (Cytokine-induced neutrophil chemoattractant), MCP (Monocyte chemotactic protein), CCL2 (chemokine (C-C motif) ligand), TGF- $\beta$ (Transforming growth factor), NADPH (Nicotinamide adenine dinucleotide phosphate), and NFR-2 (Nuclear factor (erythroid-derived 2)-like 2).

\section{ACUTE LUNG INJURY}

Inflammation related to aspiration and reflux not only plays an important role in chronic respiratory diseases such as asthma, COPD, IPF, Cystic Fibrosis, and in the post lung transplant population, it is also apparent that it plays a significant role in acute respiratory illness. Aspiration-induced lung injury often goes unrecognized in critically ill patients and it is postulated that it may account for a significant proportion of acute pulmonary dysfunction in this setting [39]. Despite this, aspiration is well recognized as an independent risk factor for the subsequent development of pneumonia or acute lung injury or acute respiratory distress syndrome (ALI/ARDS) [48]. The underlying mechanisms responsible for the progression to severe pulmonary inflammation with ensuing ALI/ARDS as a result of gastric 
aspiration are not fully understood. In a prospective study of critically ill patients, Metheny and colleagues found that in patients who were ventilated and tube fed for a minimum of 4 days that at least one aspiration event occurred in almost $90 \%$ of the patients [49]. The degree of lung injury as a consequence of gastric aspiration ranges from mild pneumonitis to severe, progressive respiratory failure with an associated significant detrimental impact on patient outcome. It has been recognized therefore that gastric aspiration may directly cause ALI and the more severe clinical phenotype, ARDS [39, 50 - 52]. The clinical development of ALI/ARDS typically involves a sudden, severe pulmonary inflammatory injury with the loss of integrity of alveolar-capillary permeability. Hence, this injury may result in alveolar edema, loss of lung compliance, hypoxemia, and frequently is associated with multi-organ system failure [39, 42]. The economic and healthcare impact of ALI/ARDS is significant, with economic costs of $3.5-6$ billion dollars and mortality levels of $30-40 \%$ reported in the United States [53, 54]. Furthermore, aspiration pneumonitis and ensuing ALI/ARDS is believed to account for up to $20 \%$ of all deaths attributable to anesthesia [55 - 57].

Animal experimental models of the acid component of gastric aspirates are frequently created by intra-tracheal instillation of HCL. Following aspiration of dilute HCL, lung injury in adult rats is characterized by a biphasic response. The early phase insult is mediated by stimulation of capsaicin sensitive neurons as well as the direct caustic actions of low $\mathrm{pH}$ on airway epithelium, and is followed by an acute neutrophilic inflammatory response at 4-6 hours [58]. The combination of these mechanisms leads to the loss of microvascular integrity, extravasation of fluid and protein into the airways and alveoli. The presence of fluid secondary to oedema may reduce airway compliance while the plasma proteins in the oedema fluid can directly interfere with alveolar surfactant function. Aspiration of low $\mathrm{pH}$ gastric contents is characterized by a neutrophilic airway influx. Levels of TNF- $\alpha$ and concentrations of several important chemotactic cytokines (chemokines) in BAL have also been found to be elevated following gastric aspiration [59, 60] Fig. (1). This includes elevated levels of the neutrophil chemotactic chemokine IL-8 in rabbits, or CXCL2 and cytokine induced neutrophil chemoattractant-1 (CINC-1) in rodents, during acid induced lung injury [40, 41, 61]. Levels of leukocyte derived oxidants and proteinases, including elastase have similarly been shown to be increased in acid-induced lung injury $[62,63]$. Activation of complement is also described as important in the systemic response and the consequent injury that occurs following gastric aspiration [64].

Recruitment of neutrophils and release of reactive oxygen species are considered to be major pathogenic components driving ALI. However, NADPH oxidase, the major source of reactive oxygen species in activated phagocytes, can paradoxically limit inflammation and injury. NADPH oxidase generates the oxidative "burst" in PMNs, leading to the production of ROS (reactive oxygen species) and activation and release of PMN granular proteases [65 68] In addition to this enzyme's critical host defense function, NADPH oxidase also regulates inflammation. In studies of lung inflammation induced by microbial-derived products, NADPH oxidase restrained lung inflammation by activation of Nrf2, a redox-sensitive anti-oxidative and anti-inflammatory transcription factor [66]. Experiments by Davidson et al. in mice models of ALI showed that NADPH oxidase activation leads to rapid generation of ROS and activation of PMN granular proteases responsible for killing invading pathogens [69]. While initial actions are clearly injurious, the study demonstrated that NADPH oxidase could also counterbalance these early pro-inflammatory and injurious events.

\section{ANTI-INFLAMMATORY TREATMENT}

Our knowledge of the pathogenesis of reflux mediated cell injury has exponentially expanded over the last number of years. However, despite an improved understanding of the mechanisms involved, this has not led to any new forms of treatment. Despite the acknowledgement that pepsin, bile salts, acidic and non-acidic reflux play interchangeable roles in the end pathology of aspiration, treatment options are still restricted to proton pump inhibitors (PPI) and surgical intervention, both of which have yielded mixed results. Understanding of the role played by PPIs comes from studies looking at their effect on acidic bile salts. Huo et al. demonstrated the omeprazole inhibits IL-8 secretion stimulated by exposure to acid and bile salts from esophageal epithelial cell [70]. They demonstrated that acidic bile salts activate the IL- 8 promoter through nuclear factor (NF)- $\kappa$ B and activator protein (AP)-1 DNA binding sites, and that the omeprazole inhibits IL-8 production by blocking nuclear translocation of p65, as well as decreased binding of p65, c-jun and c-fos to the IL-8 promoter. These effects were independent of the effects on gastric acid secretion demonstrating a novel mechanism that might contribute to the beneficial effects of PPIs in the treatment of reflux related pulmonary inflammation. The caveat to this finding comes in research by Pauwels et al. examining the effect of aspirate of CF patients being treated with a PPI, that showed a significantly enhanced inflammatory effect (higher IL-8 production) on CF bronchial epithelial cells in culture. As chronic PPI treatment in CF may result in a paradoxically increased inflammatory effect in the airways, alternative anti-reflux therapies should be considered in CF. If 
uncontrolled GORD is present and medical management fails, fundoplication may have a role in preserving lung function and improving pulmonary status in a small, carefully selected patient group [71]. Interleukin- 6 is one of the key mediators of fibrosis in chronic inflammation in animal models, and it may be that better understanding of these critical elements within the inflammatory cascade may yield pharmacogenic therapies in the years to come.

\section{CONCLUSION}

Available clinical and experimental evidence points to a possible relationship between the progression of airways disease, pro-inflammatory processes and gastric aspiration. In order to progress this further it is now critical to initiate development and implementation of pharmacological or surgical interventions in the relevant patient groups, targeted at reducing gastric aspiration rates with objective measures of airways disease as the primary outcomes in adequately powered, controlled studies. Such studies will ultimately allow us to determine whether any causal relationship between aspiration and severity of airways disease does indeed exist.

\section{CONSENT FOR PUBLICATION}

Not applicable.

\section{AVAILABILITY OF DATA AND MATERIAL}

Not applicable.

\section{FUNDING}

The authors are funded by the Wilton Respiratory Research Fund, Denis O' Sullivan Fellowship award (EH) and the APC Microbiome Institute.

\section{AUTHOR CONTRIBUTIONS}

All authors were involved in writing the manuscript. DMM, EH and JMS edited, read and approved the final manuscript. All authors confirm that the content of the manuscript has not been published, or submitted for publication elsewhere. The authors listed certify that they have no conflict of interest with regards to the subject matter or materials discussed in this manuscript.

\section{CONFLICT OF INTEREST}

The authors declare no conflict of interest, financial or otherwise.

\section{ACKNOWLEDGEMENTS}

The reported study was funded by RFBR, research project No. 16-34-60147 mol_a_dk.

\section{REFERENCES}

[1] Dent J, El-Serag HB, Wallander MA, Johansson S. Epidemiology of gastro-oesophageal reflux disease: A systematic review. Gut 2005; 54(5): $710-7$.

[http://dx.doi.org/10.1136/gut.2004.051821] [PMID: 15831922]

[2] Sweet MP, Patti MG, Hoopes C, Hays SR, Golden JA. Gastro-oesophageal reflux and aspiration in patients with advanced lung disease. Thorax 2009; 64(2): 167-73.

[http://dx.doi.org/10.1136/thx.2007.082719] [PMID: 19176842]

[3] Hu X, Lee JS, Pianosi PT, Ryu JH. Aspiration-related pulmonary syndromes. Chest 2015; 147(3): 815-23. [http://dx.doi.org/10.1378/chest.14-1049] [PMID: 25732447]

[4] Marik PE. Pulmonary aspiration syndromes. Curr Opin Pulm Med 2011; 17(3): 148-54. [http://dx.doi.org/10.1097/MCP.0b013e32834397d6] [PMID: 21311332]

[5] Song Y, Thiagarajah J, Verkman AS. Sodium and chloride concentrations, pH, and depth of airway surface liquid in distal airways. J Gen Physiol 2003; 122(5): 511-9.

[http://dx.doi.org/10.1085/jgp.200308866] [PMID: 14557401]

[6] Davidson BA, Knight PR, Wang Z, et al. Surfactant alterations in acute inflammatory lung injury from aspiration of acid and gastric particulates. Am J Physiol Lung Cell Mol Physiol 2005; 288(4): L699-708. [http://dx.doi.org/10.1152/ajplung.00229.2004] [PMID: 15757954]

[7] Sacco O, Silvestri M, Sabatini F, et al. IL-8 and airway neutrophilia in children with gastroesophageal reflux and asthma-like symptoms. 
Respir Med 2006; 100(2): 307-15.

[http://dx.doi.org/10.1016/j.rmed.2005.05.011] [PMID: 16002270]

[8] Heming TA, Davé SK, Tuazon DM, Chopra AK, Peterson JW, Bidani A. Effects of extracellular pH on tumour necrosis factor-alpha production by resident alveolar macrophages. Clin Sci 2001; 101(3): 267-74. [http://dx.doi.org/10.1042/cs1010267] [PMID: 11524044]

[9] Pezzulo AA, Tang XX, Hoegger MJ, et al. Reduced airway surface pH impairs bacterial killing in the porcine cystic fibrosis lung. Nature 2012; 487(7405): 109-13.

[http://dx.doi.org/10.1038/nature11130] [PMID: 22763554]

[10] Mayer AK, Dalpke AH. Regulation of local immunity by airway epithelial cells. Arch Immunol Ther Exp (Warsz) 2007; 55(6): 353-62. [http://dx.doi.org/10.1007/s00005-007-0041-7] [PMID: 18060372]

[11] Hackett AP, Trinick RE, Rose K, Flanagan BF, McNamara PS. Weakly acidic pH reduces inflammatory cytokine expression in airway epithelial cells. Respir Res 2016; 17(1): 82.

[http://dx.doi.org/10.1186/s12931-016-0399-3] [PMID: 27422381]

[12] Jones R, Pearson J, Ward C. Functional Dyspepsia. N Engl J Med 2016; 374(9): 895. [http://dx.doi.org/10.1056/NEJMc1515497] [PMID: 26962925]

[13] Al-Momani H, Perry A, Stewart CJ, et al. Microbiological profiles of sputum and gastric juice aspirates in Cystic Fibrosis patients. Sci Rep 2016; 6: 26985 .

[http://dx.doi.org/10.1038/srep26985] [PMID: 27245316]

[14] Sullivan A, Hunt E, MacSharry J, Murphy DM. The microbiome and the pathophysiology of asthma. Respir Res 2016; 17: 163. [PMID: 27919249]

[15] Piper DW, Fenton BH. pH stability and activity curves of pepsin with special reference to their clinical importance. Gut 1965; 6(5): 506-8. [http://dx.doi.org/10.1136/gut.6.5.506] [PMID: 4158734]

[16] Balan KK, Jones AT, Roberts NB, Pearson JP, Critchley M, Jenkins SA. The effects of Helicobacter pylori colonization on gastric function and the incidence of portal hypertensive gastropathy in patients with cirrhosis of the liver. Am J Gastroenterol 1996; 91(7): 1400-6. [PMID: 8678003]

[17] Metheny NA, Chang YH, Ye JS, et al. Pepsin as a marker for pulmonary aspiration. Am J Crit Care 2002; 11(2): 150-4. [PMID: 11888127]

[18] Farrell S, McMaster C, Gibson D, Shields MD, McCallion WA. Pepsin in bronchoalveolar lavage fluid: A specific and sensitive method of diagnosing gastro-oesophageal reflux-related pulmonary aspiration. J Pediatr Surg 2006; 41(2): 289-93. [http://dx.doi.org/10.1016/j.jpedsurg.2005.11.002] [PMID: 16481237]

[19] Farhath S, Aghai ZH, Nakhla T, et al. Pepsin, a reliable marker of gastric aspiration, is frequently detected in tracheal aspirates from premature ventilated neonates: Relationship with feeding and methylxanthine therapy. J Pediatr Gastroenterol Nutr 2006; 43(3): 336-41. [http://dx.doi.org/10.1097/01.mpg.0000232015.56155.03] [PMID: 16954956]

[20] Stovold R, Forrest IA, Corris PA, et al. Pepsin, a biomarker of gastric aspiration in lung allografts: A putative association with rejection. Am J Respir Crit Care Med 2007; 175(12): 1298-303.

[http://dx.doi.org/10.1164/rccm.200610-1485OC] [PMID: 17413126]

[21] Farhath S, He Z, Nakhla T, et al. Pepsin, a marker of gastric contents, is increased in tracheal aspirates from preterm infants who develop bronchopulmonary dysplasia. Pediatrics 2008; 121(2): e253-9. [http://dx.doi.org/10.1542/peds.2007-0056] [PMID: 18245400]

[22] Tobey NA, Hosseini SS, Caymaz-Bor C, Wyatt HR, Orlando GS, Orlando RC. The role of pepsin in acid injury to esophageal epithelium. Am J Gastroenterol 2001; 96(11): 3062-70 [http://dx.doi.org/10.1111/j.1572-0241.2001.05260.x] [PMID: 11721751]

[23] Bathoorn E, Daly P, Gaiser B, et al. Cytotoxicity and induction of inflammation by pepsin in Acid in bronchial epithelial cells. Int J Inflam 2011. 2011: 569416

[24] Pauwels A, Decraene A, Blondeau K, et al. Bile acids in sputum and increased airway inflammation in patients with cystic fibrosis. Chest 2012; 141(6): 1568-74.

[http://dx.doi.org/10.1378/chest.11-1573] [PMID: 22135379]

[25] D’Ovidio F, Mura M, Tsang M, et al. Bile acid aspiration and the development of bronchiolitis obliterans after lung transplantation. J Thorac Cardiovasc Surg 2005; 129(5): 1144-52. [http://dx.doi.org/10.1016/j.jtcvs.2004.10.035] [PMID: 15867792]

[26] Palm K, Sawicki G, Rosen R. The impact of reflux burden on Pseudomonas positivity in children with cystic fibrosis. Pediatr Pulmonol 2012; 47(6): 582-7. [http://dx.doi.org/10.1002/ppul.21598] [PMID: 22162484]

[27] Reen FJ, Woods DF, Mooij MJ, Adams C, O'Gara F. Respiratory pathogens adopt a chronic lifestyle in response to bile. PLoS One 2012; 7(9): e45978.

[http://dx.doi.org/10.1371/journal.pone.0045978] [PMID: 23049911] 
[28] van der Doef HP, Arets HG, Froeling SP, Westers P, Houwen RH. Gastric acid inhibition for fat malabsorption or gastroesophageal reflux disease in cystic fibrosis: Longitudinal effect on bacterial colonization and pulmonary function. J Pediatr 2009; 155(5): 629-33. [http://dx.doi.org/10.1016/j.jpeds.2009.06.040] [PMID: 19683256]

[29] Vos R, Blondeau K, Vanaudenaerde BM, et al. Airway colonization and gastric aspiration after lung transplantation: Do birds of a feather flock together? J Heart Lung Transplant 2008; 27(8): 843-9. [http://dx.doi.org/10.1016/j.healun.2008.05.022] [PMID: 18656796]

[30] Gibson RL, Burns JL, Ramsey BW. Pathophysiology and management of pulmonary infections in cystic fibrosis. Am J Respir Crit Care Med 2003; 168(8): 918-51. [http://dx.doi.org/10.1164/rccm.200304-505SO] [PMID: 14555458]

[31] O’Sullivan BP, Freedman SD. Cystic fibrosis. Lancet 2009; 373(9678): 1891-904. [http://dx.doi.org/10.1016/S0140-6736(09)60327-5] [PMID: 19403164]

[32] Appel JZ III, Lee SM, Hartwig MG, et al. Characterization of the innate immune response to chronic aspiration in a novel rodent model. Respir Res 2007; 8: 87. [http://dx.doi.org/10.1186/1465-9921-8-87] [PMID: 18042282]

[33] Eltzschig HK, Carmeliet P. Hypoxia and inflammation. N Engl J Med 2011; 364(7): 656-65. [http://dx.doi.org/10.1056/NEJMra0910283] [PMID: 21323543]

[34] Nizet V, Johnson RS. Interdependence of hypoxic and innate immune responses. Nat Rev Immunol 2009; 9(9): 609-17. [http://dx.doi.org/10.1038/nri2607] [PMID: 19704417]

[35] Zinkernagel AS, Johnson RS, Nizet V. Hypoxia inducible factor (HIF) function in innate immunity and infection. J Mol Med (Berl) 2007; 85(12): 1339-46. [http://dx.doi.org/10.1007/s00109-007-0282-2] [PMID: 18030436]

[36] Cramer T, Yamanishi Y, Clausen BE, et al. HIF-1alpha is essential for myeloid cell-mediated inflammation. Cell 2003; $112(5)$ : 645-57. [http://dx.doi.org/10.1016/S0092-8674(03)00154-5] [PMID: 12628185]

[37] Peyssonnaux C, Datta V, Cramer T, et al. HIF-1alpha expression regulates the bactericidal capacity of phagocytes. J Clin Invest 2005; 115(7): 1806-15. [http://dx.doi.org/10.1172/JCI23865] [PMID: 16007254]

[38] Legendre C, Reen FJ, Woods DF, Mooij MJ, Adams C, O'Gara F. Bile acids repress hypoxia-inducible factor 1 signaling and modulate the airway immune response. Infect Immun 2014; 82(9): 3531-41. [http://dx.doi.org/10.1128/IAI.00674-13] [PMID: 24914220]

[39] Marik PE. Aspiration pneumonitis and aspiration pneumonia. N Engl J Med 2001; 344(9): 665-71. [http://dx.doi.org/10.1056/NEJM200103013440908] [PMID: 11228282]

[40] Knight PR, Davidson BA, Nader ND, et al. Progressive, severe lung injury secondary to the interaction of insults in gastric aspiration. Exp Lung Res 2004; 30(7): 535-57.

[http://dx.doi.org/10.1080/01902140490489162] [PMID: 15371091]

[41] Shanley TP, Davidson BA, Nader ND, et al. Role of macrophage inflammatory protein-2 in aspiration-induced lung injury. Crit Care Med 2000; 28(7): 2437-44. [http://dx.doi.org/10.1097/00003246-200007000-00041] [PMID: 10921576]

[42] Rose CE Jr, Sung SS, Fu SM. Significant involvement of CCL2 (MCP-1) in inflammatory disorders of the lung. Microcirculation 2003; 10(3-4): 273-88. [http://dx.doi.org/10.1080/mic.10.3-4.273.288] [PMID: 12851645]

[43] Davidson BA, Knight PR, Helinski JD, Nader ND, Shanley TP, Johnson KJ. The role of tumor necrosis factor-alpha in the pathogenesis of aspiration pneumonitis in rats. Anesthesiology 1999; 91(2): 486-99.

[http://dx.doi.org/10.1097/00000542-199908000-00024] [PMID: 10443613]

[44] Manderscheid PA, Bodkin RP, Davidson BA, Jensen E, Russo TA, Knight PR. Bacterial clearance and cytokine profiles in a murine model of postsurgical nosocomial pneumonia. Clin Diagn Lab Immunol 2004; 11(4): 742-51. [PMID: 15242950]

[45] Shea LM, Beehler C, Schwartz M, Shenkar R, Tuder R, Abraham E. Hyperoxia activates NF-kappaB and increases TNF-alpha and IFNgamma gene expression in mouse pulmonary lymphocytes. J Immunol 1996; 157(9): 3902-8. [PMID: 8892621]

[46] Bremner P, Heinrich M. Natural products as targeted modulators of the nuclear factor-kappaB pathway. J Pharm Pharmacol 2002; 54(4): 453-72. [http://dx.doi.org/10.1211/0022357021778637] [PMID: 11999122]

[47] Li HD, Zhang QX, Mao Z, Xu XJ, Li NY, Zhang H. Exogenous interleukin-10 attenuates hyperoxia-induced acute lung injury in mice. Exp Physiol 2015; 100(3): 331-40. [http://dx.doi.org/10.1113/expphysiol.2014.083337] [PMID: 25480159]

[48] Raghavendran K, Nemzek J, Napolitano LM, Knight PR. Aspiration-induced lung injury. Crit Care Med 2011; 39(4): 818-26. [http://dx.doi.org/10.1097/CCM.0b013e31820a856b] [PMID: 21263315] 
[49] Metheny NA, Clouse RE, Chang YH, Stewart BJ, Oliver DA, Kollef MH. Tracheobronchial aspiration of gastric contents in critically ill tubefed patients: Frequency, outcomes, and risk factors. Crit Care Med 2006; 34(4): 1007-15. [http://dx.doi.org/10.1097/01.CCM.0000206106.65220.59] [PMID: 16484901]

[50] Ware LB, Matthay MA. The acute respiratory distress syndrome. N Engl J Med 2000; 342(18): 1334-49. [http://dx.doi.org/10.1056/NEJM200005043421806] [PMID: 10793167]

[51] Raghavendran K, Davidson BA, Helinski JD, et al. A rat model for isolated bilateral lung contusion from blunt chest trauma. Anesth Analg 2005; 101(5): 1482-9. [http://dx.doi.org/10.1213/01.ANE.0000180201.25746.1F] [PMID: 16244015]

[52] Ware LB, Matthay MA. The acute respiratory distress syndrome. N Engl J Med 2000; 342(18): $1334-49$. [http://dx.doi.org/10.1056/NEJM200005043421806] [PMID: 10793167]

[53] Goss CH, Brower RG, Hudson LD, Rubenfeld GD. Incidence of acute lung injury in the United States. Crit Care Med 2003; $31(6)$ : 1607-11. [http://dx.doi.org/10.1097/01.CCM.0000063475.65751.1D] [PMID: 12794394]

[54] Treggiari MM, Hudson LD, Martin DP, Weiss NS, Caldwell E, Rubenfeld G. Effect of acute lung injury and acute respiratory distress syndrome on outcome in critically ill trauma patients. Crit Care Med 2004; 32(2): 327-31. [http://dx.doi.org/10.1097/01.CCM.0000108870.09693.42] [PMID: 14758144]

[55] Bannister WK, Sattilaro AJ. Vomiting and aspiration during anesthesia. Anesthesiology 1962; 23: 251-64. [http://dx.doi.org/10.1097/00000542-196203000-00012] [PMID: 13864692]

[56] Bodlander FM. Deaths associated with anaesthesia. Br J Anaesth 1975; 47(1): 36-40. [http://dx.doi.org/10.1093/bja/47.1.36] [PMID: 1148073]

[57] Marx GF, Mateo CV, Orkin LR. Computer analysis of postanesthetic deaths. Anesthesiology 1973; 39(1): 54-8. [http://dx.doi.org/10.1097/00000542-197307000-00010] [PMID: 4786951]

[58] Kennedy TP, Johnson KJ, Kunkel RG, Ward PA, Knight PR, Finch JS. Acute acid aspiration lung injury in the rat: Biphasic pathogenesis. Anesth Analg 1989; 69(1): 87-92. [http://dx.doi.org/10.1213/00000539-198907000-00017] [PMID: 2742173]

[59] Kudoh I, Ohtake M, Nishizawa H, et al. The effect of pentoxifylline on acid-induced alveolar epithelial injury. Anesthesiology 1995; 82(2): $531-41$ [http://dx.doi.org/10.1097/00000542-199502000-00023] [PMID: 7856911]

[60] Goldman G, Welbourn R, Kobzik L, Valeri CR, Shepro D, Hechtman HB. Tumor necrosis factor-alpha mediates acid aspiration-induced systemic organ injury. Ann Surg 1990; 212(4): 513-9. [http://dx.doi.org/10.1097/00000658-199010000-00013] [PMID: 2222016]

[61] Folkesson HG, Matthay MA, Hébert CA, Broaddus VC. Acid aspiration-induced lung injury in rabbits is mediated by interleukin-8-dependent mechanisms. J Clin Invest 1995; 96(1): 107-16. [http://dx.doi.org/10.1172/JCI118009] [PMID: 7615779]

[62] Knight PR, Druskovich G, Tait AR, Johnson KJ. The role of neutrophils, oxidants, and proteases in the pathogenesis of acid pulmonary injury. Anesthesiology 1992; 77(4): 772-8. [http://dx.doi.org/10.1097/00000542-199210000-00023] [PMID: 1416175]

[63] Goldman G, Welbourn R, Kobzik L, Valeri CR, Shepro D, Hechtman HB. Reactive oxygen species and elastase mediate lung permeability after acid aspiration. J Appl Physiol 1992; 73(2): 571-5. [http://dx.doi.org/10.1152/jappl.1992.73.2.571] [PMID: 1399982]

[64] Nishizawa H, Yamada H, Miyazaki H, et al. Soluble complement receptor type 1 inhibited the systemic organ injury caused by acid instillation into a lung. Anesthesiology 1996; 85(5): 1120-8. [http://dx.doi.org/10.1097/00000542-199611000-00021] [PMID: 8916830]

[65] Reeves EP, Lu H, Jacobs HL, et al. Killing activity of neutrophils is mediated through activation of proteases by $\mathrm{K}^{+}$flux. Nature 2002; 416(6878): 291-7. [http://dx.doi.org/10.1038/416291a] [PMID: 11907569]

[66] Brinkmann V, Reichard U, Goosmann C, et al. Neutrophil extracellular traps kill bacteria. Science 2004; 303(5663): 1532-5. [http://dx.doi.org/10.1126/science.1092385] [PMID: 15001782]

[67] Bianchi M, Hakkim A, Brinkmann V, et al. Restoration of NET formation by gene therapy in CGD controls aspergillosis. Blood 2009; 114(13): 2619-22. [http://dx.doi.org/10.1182/blood-2009-05-221606] [PMID: 19541821]

[68] Segal BH, Han W, Bushey JJ, et al. NADPH oxidase limits innate immune responses in the lungs in mice. PLoS One 2010; 5(3): e9631. [http://dx.doi.org/10.1371/journal.pone.0009631] [PMID: 20300512]

[69] Davidson BA, Vethanayagam RR, Grimm MJ, et al. NADPH oxidase and Nrf2 regulate gastric aspiration-induced inflammation and acute lung injury. J Immunol 2013; 190(4): 1714-24. [http://dx.doi.org/10.4049/jimmunol.1202410] [PMID: 23296708]

[70] Huo X, Zhang X, Yu C, et al. In oesophageal squamous cells exposed to acidic bile salt medium, omeprazole inhibits IL-8 expression through 
effects on nuclear factor- $\kappa \mathrm{B}$ and activator protein-1. Gut 2014; 63(7): 1042-52.

[http://dx.doi.org/10.1136/gutjnl-2013-305533] [PMID: 24048734]

[71] Pauwels A, Verleden S, Farre R, et al. The effect of gastric juice on interleukin-8 production by cystic fibrosis primary bronchial epithelial cells. J Cyst Fibros 2013; 12(6): 700-5.

[http://dx.doi.org/10.1016/j.jcf.2013.03.006] [PMID: 23611945]

\section{(C) 2018 Hunt et al.}

This is an open access article distributed under the terms of the Creative Commons Attribution 4.0 International Public License (CC-BY 4.0), a copy of which is available at: https://creativecommons.org/licenses/by/4.0/legalcode. This license permits unrestricted use, distribution, and reproduction in any medium, provided the original author and source are credited. 